\title{
CHROMOSOMES IN PAEDIATRICS
}

\author{
M. D. Hayward, B.Sc. \\ Research Assistant, Departments of Genetics, and Padiatrics and Child Health, University of Birmingham \\ A. H. Cameron, M.D. \\ Consultant Pathologist, The Children's Hospital, Birmingham \\ O. H. WolfF, M.D., M.R.C.P., D.C.H. \\ Senior Lecturer and First Assistant, Department of Padiatrics and Child Health, University of Birmingham
}

THE study of chromosomal morphology in relation to human disease dates from the discovery by Barr, Bertram and Lindsay (1950), of an intranuclear chromatin mass in cells of females. Such cells are termed 'chromatin positive'. Though the initial histological observations were made in laboratory animals they were soon found to be true for man (Moore, Graham and Barr, 1953). Normal human females are chromatin positive, and normal males chromatin negative. Later the investigation of nuclear sex was greatly simplified by the examination of cells smeared from the buccal mucosa (Moore and Barr, 1955). It was subsequently discovered that males with Klinefelter's syndrome are chromatin positive (Plunkett and Barr, 1956) and females with Turner's syndrome chromatin negative (Wilkins, Grumbach and van Wyk, 1954).

The next major advance was the detailed study of chromosomes by the squash technique. The normal number of chromosomes in human cells, previously thought to be 48 , was then found to be 46 (Tjio and Levan, 1956). The chromatin body of Barr was found to correspond with the XX pair of sex chromosomes in the female and it was established that in chromatin-positive Klinefelter's syndrome the sex chromosomes consist of XXY (Jacobs and Strong, 1959), and that in chromatin-negative females with Turner's syndrome there is a single $\mathrm{X}$ and no $\mathrm{Y}$ (Ford, Jones, Polani, de Almeida and Briggs, 1959). Abmormalities have been detected in the non-sex chromosomes (autosomes) as well as in the sex chromosomes; thus Lejeune, Gautier and Turpin (r959) and Jacobs, Baikie, Brown and Strong (1959) showed that in mongolism there is an extra autosome, so that instead of a pair of chromosomes 21, there are three (trisomy). These techniques have much to offer in the study of disease in childhood and it is our intention to summarise the present state of knowledge of chromosomal abnormalities with particular ference to pædiatrics.

\section{Methods and Findings in the Normal}

In Barr's method epithelial cells in a smear take from the buccal surface of the cheek are examinedo The process is painless, simple and reliable and is easily performed even in infants. The best results are obtained if the smears are taken and stained by someone experienced in making such preparations but if necessary the fixed smears cam be posted to the laboratory for staining examination. If only well-stained cells are exe amined, Barr bodies are seen in about $40 \%$. female cells and not in male cells. The metho can be applied to fixed tissues obtained at biops or autopsy, and by ante-natal examination oo amniotic fluid the foetal sex can be determine (Riis and Fuchs, 1960). 'Drumsticks' in poly 3 morphonuclear leucocytes probably correspond te the chromatin bodies of tissue cells. In females. they are present in less than $10 \%$ of leucocyteso Male leucocytes contain smaller, similar bodies but no true 'drumsticks'. The relatively low positive count in normal females and the possible confusio between true and pseudo 'drumsticks' make thig a fallible examination in inexperienced hands, but those who practice it regularly have proved its reliability (Davidson and Smith, I954; Davidson 1960). Details of these techniques and theie application are given by Barr (1960). ON

Buccal smears are of no value in the study of autosomes, but precise information concerning a chromosomes can be obtained by culture methods There are two techniques in general use. These are the short-term culture of leucocytes from $I Q$ to $20 \mathrm{ml}$. of blood (Hungerford, Donnellyes Nowell and Beck, 1959) or bone marrow (Ford Jacobs and Lajtha, 1958), and the long-terng culture of skin or muscle. The first involves thes incubation of the material in a growth mediurf 


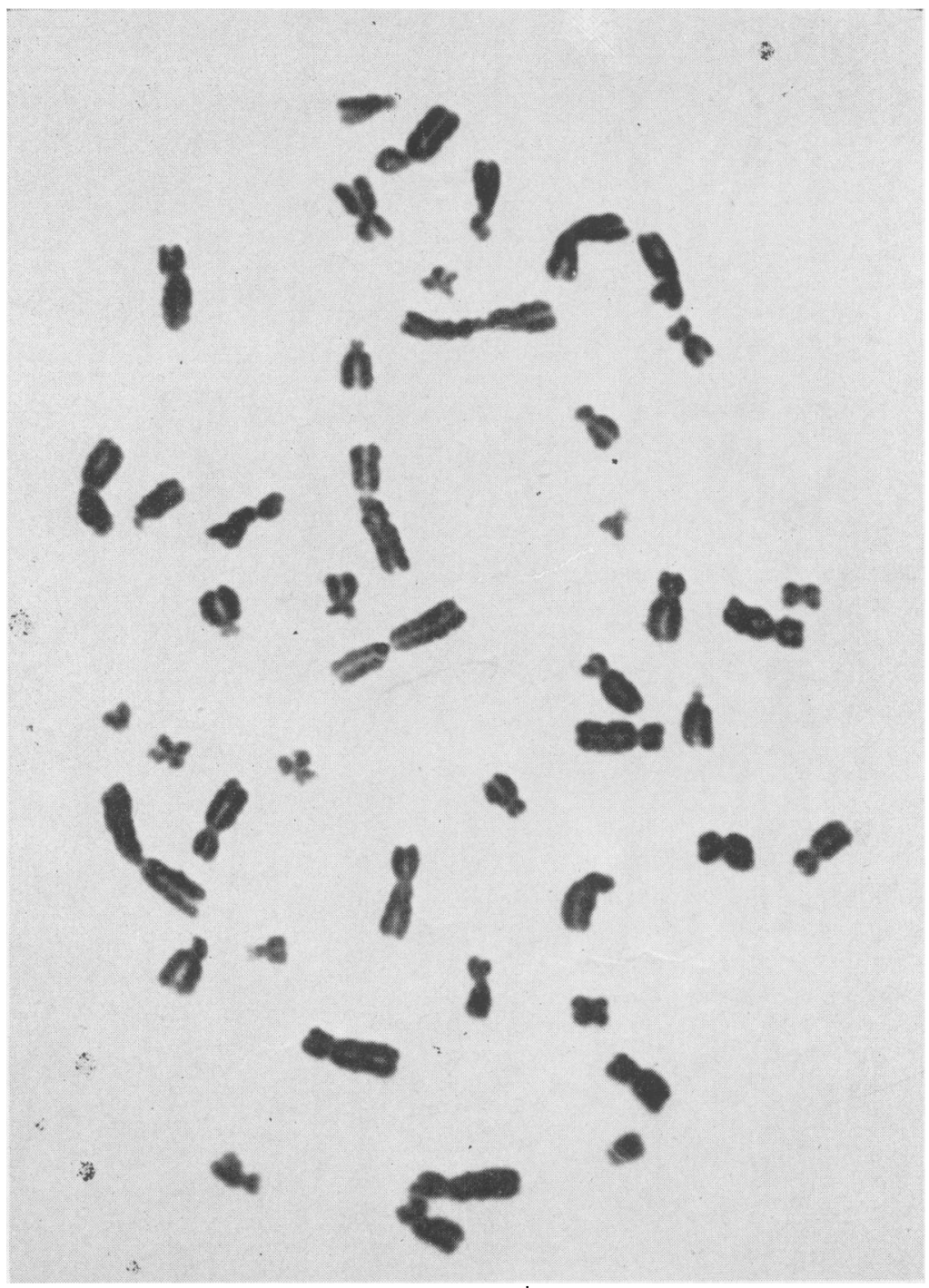

Fig. 1.-The chromosomes of a normal leucocyte.

until the number of mitotic (somatic cell) divisions reaches a maximum: colchinine is then added to inhibit the formation of the cell spindle and mitosis is arrested in metaphase when the chromosomes are most clearly defined. The cell suspension is treated with hypotonic sodium citrate which swells the cells and aids the spreading of chromosomes. After fixation the cells are stained, usually by the Feulgen technique. The longer-term culture of skin or muscle requires a more elaborate technique, involving tissue culture methods (Harnden, I960), which is probably out of the range of most hospital laboratories.

The normal chromosomal pattern is shown in
Fig. I. In Fig. 2 the chromosomes are numbered according to the Denver (1960) Convention. The abnormalities of sex chromosomes and autosomes so far reported are given in Tables $I$ and 2 respectively. These abnormalities are the result of one of two processes, non-disjunction and translocation.

\section{Mechanisms of Non-Disjunction and Translocation}

In non-disjunction a pair of chromosomes fail to separate during cell division and both pass into one of the daughter cells. If this occurs during meiosis the resultant gametes will show chro- 


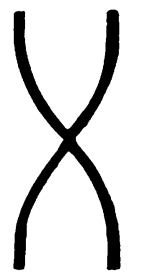

I

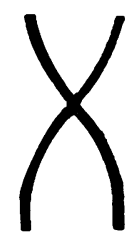

2

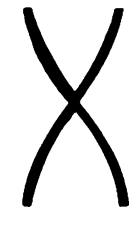

3

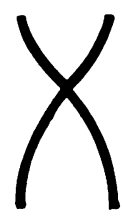

4

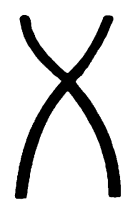

5

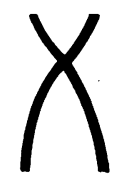

6

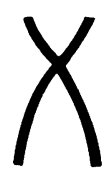

7

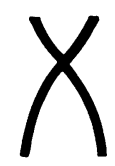

8

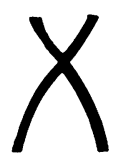

9

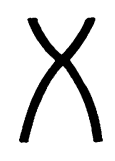

10

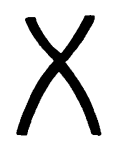

II

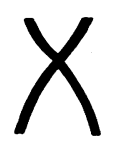

12

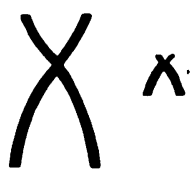

$\begin{array}{ll}X & Y\end{array}$
FIG. 2.-Idiogram normal chromo somes numbereक्ष according to the Denver Converp tion (1960). Only one of each pact of autosomes represented.

\section{$X X X X X X X \times X \times$ \\ 13 \\ $14 \quad 15$ \\ 16 \\ 17 \\ $18 \quad 19$ \\ $20 \quad 21$ \\ 22}

Fig. 3.-Non-disjunction in gametogenesis and the consequences of fertilization by normal and abnormal gametes.

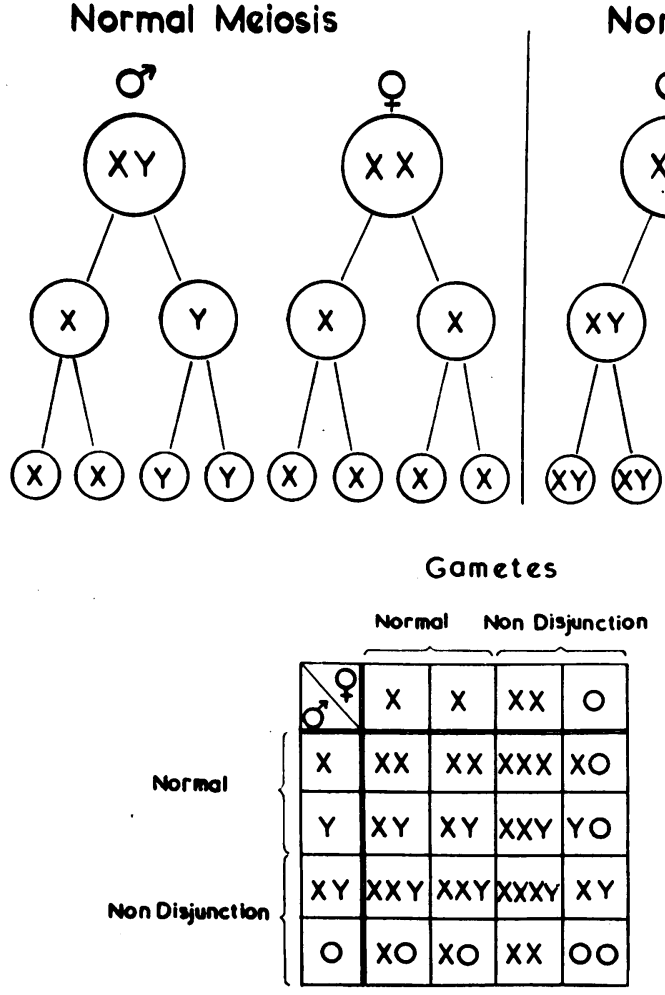

$X X=$ Normal Female

$X Y=$ Normal Male

$X X X=$ Superfemole

$X X Y=$ Klinefelter

$X X X Y=$ Primary Amentia

$X O=$ Turner

YO $=$ Non Viable

OO $=$ Ditto 
Table 1.-Cytological. Finidings in Human Sex Abnormalities

\begin{tabular}{|c|c|c|c|c|}
\hline Clinical Condition & $\begin{array}{l}\text { Pheno- } \\
\text { type }\end{array}$ & $\begin{array}{c}\text { Sex } \\
\text { Chromatin }\end{array}$ & $\begin{array}{l}\text { Sex } \\
\text { Chromosome } \\
\text { Constitution }\end{array}$ & Reference \\
\hline \multirow{3}{*}{ Klinefelter's syndrome .. } & \multirow[t]{3}{*}{ Male } & \multirow[t]{3}{*}{ Positive } & XXY & Jacobs and Strong (1959). \\
\hline & & & XXYY & Muldal and Ockey (1960). \\
\hline & & & $\mathrm{XXY} / \mathrm{XX}$ & $\begin{array}{l}\text { Ford, Polani, Briggs and Bishop (1959). } \\
\text { Hayward (1960). }\end{array}$ \\
\hline \multirow[t]{2}{*}{ 'Turner's syndrome } & \multirow[t]{2}{*}{ Female } & Negative & $\mathrm{xO}$ & $\begin{array}{l}\text { Ford, Jones, Polani, de Almeida and Briggs } \\
\text { (I959). } \\
\text { Fracarro, Kaijser and Lindsten (1959). }\end{array}$ \\
\hline & & Positive & $\mathrm{XX} / \mathrm{XO}$ & Ford (r $960 a)$ and (r $960 b)$ \\
\hline ? 'Turner's syndrome & Female & Positive & $\mathrm{XXX} / \mathrm{XO}$ & $\begin{array}{l}\text { Jacobs, Harnden, Brown, Goldstein, Close, } \\
\text { MacGregor, Maclean and Strong (1960). }\end{array}$ \\
\hline Super female $\quad$. & Female & Positive & $\mathrm{XXX}$ & $\begin{array}{l}\text { Jacobs and others (1960). } \\
\text { Fraser, Campbell, MacGillivray, Boyd and } \\
\text { Lennox (1960). }\end{array}$ \\
\hline 'Testicular feminization.. & Female & Negative & $\mathrm{XY}$ & $\begin{array}{l}\text { Jacobs, Baikie, Brown, Forrest, Roy, Stewart } \\
\text { and Lennox (1959). } \\
\text { Puck, Robinson and 'Tjio (r } 960 \text { ). }\end{array}$ \\
\hline Primary amentia & Male & Positive & $\mathrm{XXXY}$ & $\begin{array}{l}\text { Ferguson-Smith, Johnston and Handmaker } \\
\text { (1960). }\end{array}$ \\
\hline \multirow[t]{3}{*}{ True hermaphroditism } & \multirow[t]{2}{*}{ Male? } & \multirow[t]{2}{*}{ Positive } & $\mathrm{xX}$ & $\begin{array}{l}\text { Harnden and Armstrong (1959). } \\
\text { Hungerford and others (1959). } \\
\text { De Assis, Epps and Bottura (1960). }\end{array}$ \\
\hline & & & $\mathrm{XX} / \mathrm{XXX} / \mathrm{XO}$ & $\begin{array}{l}\text { Ferguson-Smith, Johnston and Weinberg } \\
\text { (1960). }\end{array}$ \\
\hline & $?$ & Negative & $\mathrm{XO} / \mathrm{XY}$ & Hirschhorn, Decker and Cooper (1960). \\
\hline Intersex ... & Female? & Negative & $\mathrm{XO} / \mathrm{XY}$ & Blank, Bishop and Caley (1960). \\
\hline
\end{tabular}

mosome unbalance, some containing two of the particular chromosome, and others none. 'The possible results of non-disjunction of the sex chromosomes in meiosis, i.e. during gametogenesis, and the consequences of fertilization by normal and abnormal gametes are shown in Fig. 3. It is noteworthy that very rarely normal zygotes may result from non-disjunction in both parents, both sex chromosomes of the female zygote being derived from the mother, and both those of the male from the father. Non-disjunction may also effect autosomes and will result in autosomal trisomy or monosomy. Non-disjunction during mitosis after formation of the zygote results in a cell population showing more than one chromosomal pattern (mosaicism). The type of mosaicism depends upon the stage of development of the zygote at the time of non-disjunction (Fig. 4). When it occurs at the first cleavage division the result will be two-cell types, but when it occurs at the second or a subsequent division three-cell types will be produced. In Turner's syndrome for example, we have recently observed a mosaic of three-cell types (XXX/XX/XO).

Translocation involves reciprocal transfer of segments of chromosomes by a process of breakage and re-union between non-homologous chromosomes (Fig. 5). When unequal segments are involved translocation can be detected at mitosis since the chromosomes cannot be paired off as in the normal idiogram. When equal segments are involved it can only be detected during meiosis in gonadal tissue when an unusual configuration of four chromosomes will be seen. Translocation does not affect the individual in whom it occurs as the total chromosomal content is unaltered, but depending upon the behaviour at meiosis an abnormal gamete may result. Fertilization by a normal gamete will result in the production of a zygote with an unbalanced chromosome content. An example of this has been described in a child with 'polydysspondylie' (Turpin, Lejeune, 
TABLE 2

Human Autosome Abnormalities

\begin{tabular}{|c|c|c|}
\hline $\begin{array}{c}\text { Clinical } \\
\text { Condition }\end{array}$ & $\begin{array}{l}\text { Autosome } \\
\text { Abnormality }\end{array}$ & Reference \\
\hline \multirow[t]{2}{*}{ Mongolism } & $\begin{array}{l}\text { Trisomy } \\
\text { chromosome, } \\
2 \text { I }\end{array}$ & $\begin{array}{l}\text { Lejeune and } \\
\text { others (I959). } \\
\text { Jacobs, Baikie, } \\
\text { Brown and } \\
\text { Strong (1959). }\end{array}$ \\
\hline & $\begin{array}{l}\text { Translocation } \\
\text { anomaly }\end{array}$ & $\begin{array}{l}\text { Polani and } \\
\text { others (1960). }\end{array}$ \\
\hline $\begin{array}{l}\text { Peculiar facies and } \\
\text { digits } \\
\text { Webbed neck } \\
\text { Ventricular septal } \\
\text { defect of heart }\end{array}$ & $\begin{array}{l}\text { Trisomy } \\
\text { chromosome, } \\
\text { 17 }\end{array}$ & $\begin{array}{l}\text { Edwards and } \\
\text { others (1960). }\end{array}$ \\
\hline $\begin{array}{l}\text { Cerebral defect } \\
\text { Simian creases } \\
\text { Trigger thumbs } \\
\text { Polydactyly } \\
\text { Capillary } \\
\text { hæmangiomata } \\
\text { Hare lip } \\
\text { Cleft palate } \\
\text { Apparent } \\
\text { anophthalmia } \\
\text { Heart defect }\end{array}$ & $\begin{array}{l}\text { Trisomy } \\
\text { chromosome, } \\
\text { I } 5\end{array}$ & $\begin{array}{l}\text { Patau and others } \\
\text { (1960). }\end{array}$ \\
\hline $\begin{array}{l}\text { Sturge-Weber } \\
\text { syndrome }\end{array}$ & $\begin{array}{l}\text { Trisomy } \\
\text { chromosome, } \\
22\end{array}$ & $\begin{array}{l}\text { Hayward and } \\
\text { Bower (1960). }\end{array}$ \\
\hline $\begin{array}{l}\text { Normal (father of } \\
\text { a mongol) }\end{array}$ & $\begin{array}{l}\text { Trisomy } \\
\text { chromosome, } \\
\text { I9 }\end{array}$ & $\begin{array}{l}\text { Fracarro and } \\
\text { others (1960). }\end{array}$ \\
\hline Polydysspondylie & $\begin{array}{l}\text { Translocation } \\
\text { anomaly }\end{array}$ & $\begin{array}{l}\text { Turpin and } \\
\text { others (1959). }\end{array}$ \\
\hline
\end{tabular}

Lafourcade and Gautier, 1959), in whom the greater part of one of the smallest chromosomes was found translocated on to one of a longer pair.

\section{Selection of Patients}

As full chromosomal examination is so timeconsuming it can economically be applied only to a small proportion of patients. Careful selection of those to be studied is essential and will depend on research as well as diagnostic considerations.

Virilization in females, ranging from simple enlargement of the clitoris to more complete pseudohermaphroditism, may make diagnosis of sex difficult. In these patients the buccal smear is chromatin-positive and full chromosomal investigation is not essential. Most of these cases are instances of the adreno-genital syndrome, and confirmation of the diagnosis can be rapidly obtained by the pattern of urinary steroid excretion (Hill, 1960). Others may be due to androgenic substances, including progestational steroids, given to the mother during pregnancy, and occasional no cause can be found.

The great majority of patients with hypospadias and apparently undescended testes are in fact males, nevertheless male sex should be confirmed by a buccal smear (chromatin-negative) before surgical correction is undertaken. In the syrg drome of testicular feminization the extern genitalia are typically female. The testes may intra-abdominal, in the labia majora, or in the inguinal canals, where they may be mistaken for herniæ or enlarged glands. The buccal smear is chromatin-negative and confirmation of ma尺 sex may be obtained by the finding of an XY se chromosomal constitution (Jacobs, Baikie, Brow Forrest, Roy, Stewart and Lennox, 1959).

True hermaphroditism with male and fema:e. gonadal elements is rare. The external genitality show male and female features. In the majority the buccal smear is positive (Barr, I955), and the chromosomal constitution XX (Ferguson-Smith Johnston and Weinberg, I960) but a case witథp mosaicism (XO/XY) has been reported recentf (Hirschhorn, Decker and Cooper, 1960). The diagnosis rests upon biopsy of the gonads. For (1960a) has suggested that there may be gonada mosaicism and the chromosomal constitution $\overrightarrow{a b}$ the gonads and somatic tissues should be foily investigated.

These various forms of intersex can preson difficult diagnostic problems in infancy or earrl childhood. It is a matter of urgency to establis the proper sex as soon as possible after birt⿳亠口冋 (Moore and Edwards, 1960; Wilkins, 1957). I reaching this decision determination of the chromosomal sex is essential, though it is by no means the only factor to be considered (Mone Hampson and Hampson, 1956).

In the conditions discussed above chromosoma studies are used to establish the proper sex of the patient and the sex chromosomes correspond to the gonads. True abnormalities of the sex chromog somes are more likely to manifest themselves at puberty since they result in deviations from the normal development of secondary sexual charac teristics. Two such conditions, Turner's syne drome and Klinefelter's syndrome, are now weft defined. In both there may also be mentrif retardation so that examination of the buccald smear in retarded children may lead to the्e diagnosis before puberty (Ferguson-Smith, 1958) The diagnosis of Klinefelter's syndrome is other wise unlikely to be made during childhoof though it might be suggested by the finding of un usually long legs (Tanner, Prader, Habich and Ferguson-Smith, 1959). In Turner's syndrom $\vec{\Theta}$ mental retardation occurs in only a minority, bu the other characteristic abnormalities often enable 


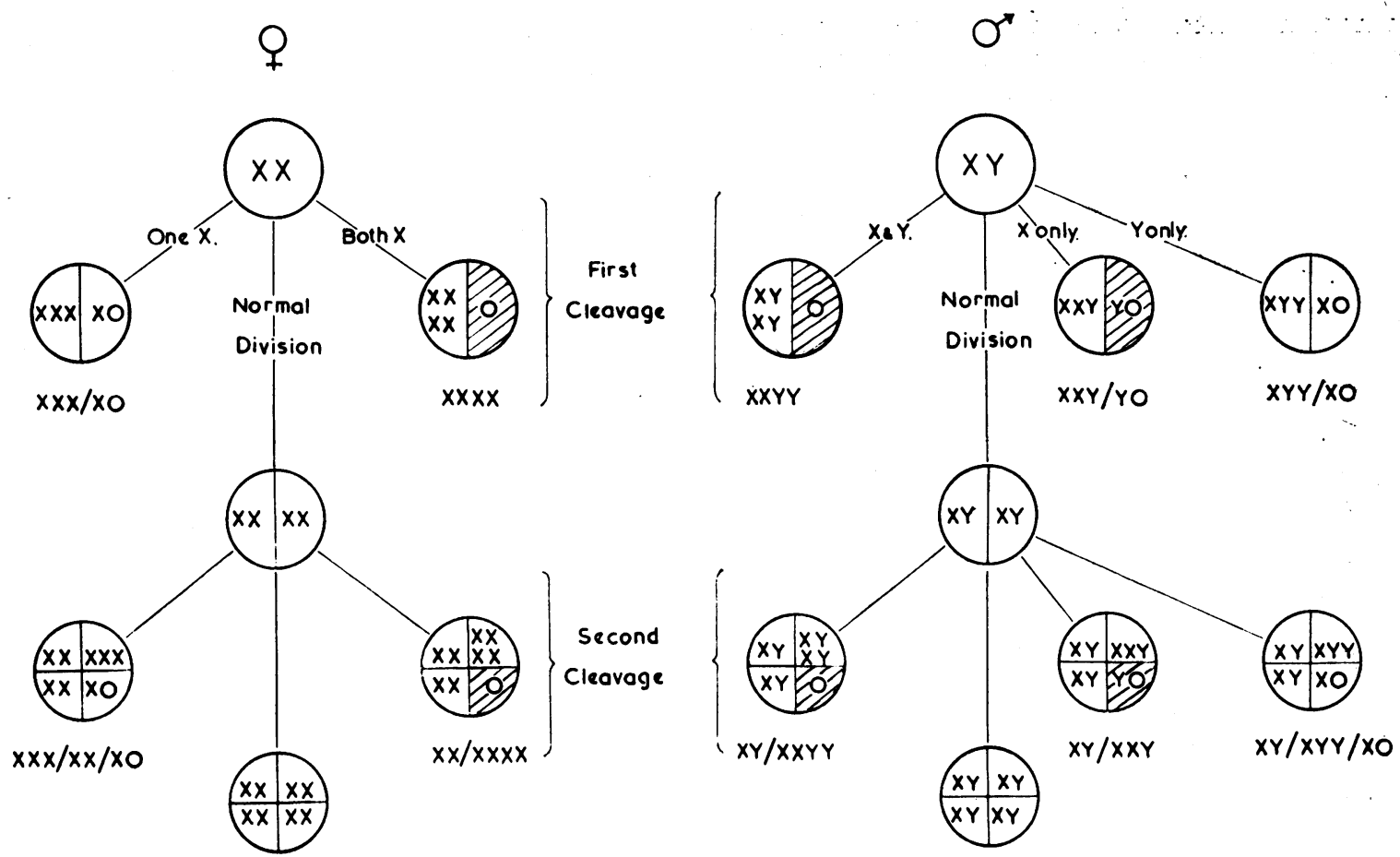

Fig. 4.-The types of mosaicism resulting from nondisjunction in the first and subsequent cleavage divisions. The shaded segments are presumed to be non-viable.

\section{Equal translocation. Non identifiable in mitotic celis.}

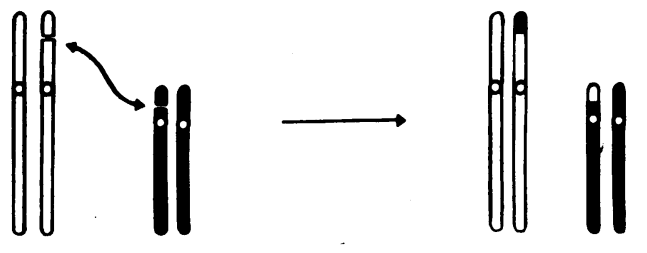

\section{Unequal translocation Identifiable in mitotic cells.}

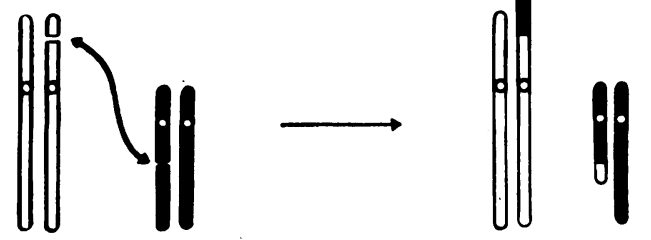

Fig. 5.-Translocation.

the diagnosis to be made during childhood. Ford (1960b) has found mosaicism (XX/XO) in a high proportion of cases of Turner's syndrome. In our patient with triple mosaicism $(\mathrm{XXX} / \mathrm{XX} / \mathrm{XO})$ already referred to, an abnormal sex chromosome constitution was suggested by a low percentage of chromatin-positive cells in the buccal smear and by the finding of double Barr bodies.

Autosomal abnormalities should be suspected in patients with multiple congenital defects in whom the buccal smear is normal. The chief example of this group is mongolism. This condition is usually the result of trisomy for chromosome 2 i but Polani, Briggs, Ford, Clarke and Berg (1960) have described a mongol with an abnormality of one of pair 15. There was no trisomy in the usual sense but they postulate that the abnormality was the result of translocation in a previous generation of the greater part of a chromosome 21 on to one of pair I5. The mother of this child was only 21 years old and the authors suggest that this or a similar mechanism, rather than the usual trisomy, may be involved in mongols of young mothers.

Another infant with multiple congenital abnormalities was found to be trisomic for chromosome 17 (Edwards, Harnden, Cameron, Crosse and Wolff, 1960), and a somewhat similar patient found to be trisomic for chromosome i8 was described by Patau, Smith, Therman, Inhorn and Wagner (1960). Undoubtedly other examples of autosomal trisomy will be discovered, though when the larger chromosomes are involved the 
condition is likely to be incompatible with embryonic survival. In general, autosomal trisomy should be suspected in patients with multiple structural abnormalities rather than in patients with single localized deformities (Edwards et al., 1960). Single gene defects are not associated with any morphological chromosomal abnormality detectable by present methods.

\section{Research Aspects}

Important advances are to be expected in the field of chromosomal research. Some of these will stem from the investigation of clinical problems as outlined above, and others from the systematic investigation of specific conditions. Further studies in leukæmia, where abnormalities have already been found (Ford, Jacobs and Lajtha, I958; Baikie, Brown, Jacobs and Milne, I959; Nowell and Hungerford, 1960) are likely to be rewarding. Willis (1958) stresses the need for more detailed investigations into the nuclear sex of teratomas. Much attention has been paid to the chromosomes in malignant tumours; the study of: embryonal tumours should be of particular interest. Because certain chromosomal abnormalities are likely to be incompatible with life, early abortions should be examined. Clinical conditions occurring predominantly in one sex are worthy of attention as abnormalities of sex chromosomes may occasionally be brought to light. For instance we have recently encountered a girl with Hirschsprung's disease, which occurs predominantly in male children, in whom mosaicism was suggested by the buccal smear, which showed only $10 \%$ chromatin positive cells, and $\frac{0}{\pi}$ confirmed by examination of the chromosomes (XO, XX, XXX). Before attaching much significance to such findings other cases must be examined to exclude the possibility of chance association. For example, since one of us (Hayward and Bower, 1960) reported a case of $\bar{C}$ Sturge-Weber syndrome with trisomy for chromo- 흠 some 22, we have examined seven other cases and $\frac{\mathcal{N}}{\vec{\sigma}}$ found no chromosomal abnormality (Hayward and $\stackrel{\varnothing}{\circ}$ Bower, 196r). So far, chromosomal abnormalities ڤ in Klinefelter's syndrome, Turner's syndrome and $\vec{\circ}$ mongolism are the only ones in which repeated observations have adequately confirmed the initial $\vec{\omega}$ findings. Apart from establishing consistent? chromosomal abnormalities in specific conditions $\frac{0}{7}$ future research must elucidate the mechanisms whereby variations in the chromosomal pattern. lead to distinctive clinical syndromes. In any such $\mathrm{i}$ investigation a greater knowledge of the range of variation of chromosomal pattern in normal $\overbrace{\infty}$ individuals is required. Already a clinicallyo normal person has been found with trisomy for chromosome 19 (Fracarro, Kaijser and Lindsten, $\vec{z}$ 1960) and indeed Kodani (1958) claims to have observed such supernumerary chromosomes frequently in male meiotic material. Confirmation of $\mathscr{\&}$ these results however, is hampered by the shortage of suitable testicular material.

In conclusion, we wish to stress the need for close co-operation between cytologist and clinician so that the limited laboratory facilities available may be used to the best advantage.

\section{REFERENCES}

Baikie, A. G., Brown, W. M. C., Jacobs, P. A., and Milne, J. S. (I959): Chromosome Studies in Human Leukæmia, Lancet, $\mathrm{ii}, 425$.

BARR, M. L. (1955): The Skin Biopsy Test of Chromosomal Sex in Clinical Practice, Anat. Rec., r21, 387.

(1960): In Recent Advances in Clinical Pathology, Chap. 2 I. London: J. and A. Churchill. , Bertram, E. G., and Lindsay, H. A. (1950): The Morphology of the Nerve Cell Nucleus According to Sex, Anat. Rec., I07, 283 .

Blank, C. E., Bishop, A., and Caley, J. P. (1960): Example of XY/XO Mosaicism, Lancet, ii, 1450.

Davidson, W. M. (1960): Sex Determination: Diagnostic Methods, Brit. med. F., ii, i 901.

- and Smith, D. R. (1954): A Morphological Sex Difference in the Polymorphonuclear Neutrophil Leucocytes, 윽 Brit. med. F., ii, 6.

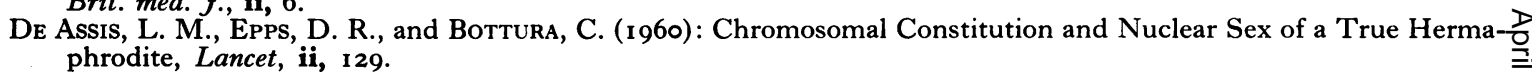
Denver Convention (1960): A Proposed Standard System of Nomenclature of Human Mitotic Chromosomes, Lancet, N
i, I063.

Edwards, J. H., Harnden, D. G., Cameron, A. H., Crosse, V. M., and Wolff, O. H. (ig6o): A New Trisomic N Syndrome, Lancet, i, 787 .

Ferguson-Smith, M. A. (1958): Chromatin-positive Klinefelter's Syndrome (Primary Micro-orchidism) in a Mental- ${ }^{-}$ deficiency Hospital, Lancet, i, 928.

, Johnston, A. W., and Handmaker, S. D. (1960): Primary Amentia and Micro-orchidism Associated with ane XXXY Sex-chromosome Constitution, Lancet, ii, 184.

-, , and Weinberg, A. N. (1960): The Chromosome Complement in True Hermaphroditism, Lancet, ii, 126.

Ford, C. E. (1960a): Human Cytogenetics: Its Present Place and Future Possibilities, Amer. F. Hum. Genet., r2, I04.

--, (r96ob): In Ciba Foundation Symposium on Congenital Malformations, p. 49. London: J. and A. Churchill.

—, JAcoBs, P. A., and Lajtha, L. G. (1958): Human Somatic Chromosomes, Nature, 181, I 565.

- Jones, K. W., Polani, P. E., de Almeida, J. C., and Briggs, J. H. (1959): A Sex Chromosome Anomaly in a Case of Gonadal Dysgenesis (Turner's Syndrome), Lancet, i, 7 II. 
Polani, P. E., Briggs, J. H., and Bishop, P. M. F. (1959): A Presumptive Human XXY/XX Mosaic, Nature, I83, I 30 .

Fracarro, M., Kaijser, K., and Lindsten, J. (1959): Chromosomal Complement in Gonadal Dysgenesis (Turner's Syndrome), Lancet, i, 886.

$--,-1-1$ ( 1960$)$ : Chromosomal Abnormalities in Father and Mongol Child, Lancet, i, 724.

Fraser, J. H., Campbell, J., MacGillivray, R. C., Boyd, E., and Lennox, B. (i960): 'The XXX Syndrome, Frequency among Mental Defectives and Fertility, Lancet, ii, 626.

Harnden, I). G. ( 1 960): A Human Skin Culture Technique used for Cytological Examination of Different Pathological Conditions, Brit. F. exp. Path., xli, 31 .

Harnden, D. G. and Armstrong, C. N. (1959): The Chromosomes of a True Hermaphrodite, Brit. med. F., ii, 1287.

Hayward, M. D. ( 1960): Sex Chromosome Mosaicism in Man, Heredity. 15, 235.

- -, and Bower, B. D. (1960): Chromosomal Trisomy Associated with the Sturge-Weber Syndrome, Lancet, ii, 844.

- - (196r): The Chromosomal Constitution of the Sturge-Weber Syndrome, Lancet (in press).

Hill, E. E. (1960): Chromatography of the I7-ketogenic Steroids in the Diagnosis and Control of Congenital Adrenal Hyperplasia, Acta endocr. $(K b h), 33,230$.

HirschHorn, K., Decker, W. H., and CoOPer, H. L. (i 960): True Hermaphroditism with XY/XO Mosaicism, Lancet, ii, 319.

Hungerford, D. A., Donnelly, A. J., Nowell, P. C., and Beck, S. (1959): The Chromosomal Constitution of a Human Phenotypic Intersex, Amer. F. hum. Genet., II, 2 I 5.

Jacobs, P. A., Baikie, A. G., Brown, W. M. C., Forrest, H., Roy, J. R., Stewart, J. S.S., and Lennox, B. (1959): Chromosomal Sex in the Syndrome of Testicular Feminization, Lancet, ii, 59I.

$-1,-1-$, and STrong, J. A. (1959): The Somatic Chromosomes in Mongolism, Lancet, i, 7 Io.

Harndf, i D. G., Brown, W. M. C., Goldstein, J., Close, H. G., MacGregor, T. N., Maclean, N., and Strong, J. A. ( 1960$)$ : Abnormalities involving the X Chromosome in Women, Lancet, $\mathbf{i}, \mathrm{I}_{2} 13$.

, and STrong, J. A. (I 959): A Case of Human Intersexuality having a possible XXY Sex-determining Mechanism, Nature, $183,302$.

Kodani, M. (1958): The Supernumerary Chromosomes of Man, Amer. F. hum. Genet., ro, i 25.

Lejeune, J., Gautier, M., and Turpin, R. (1959): Etude des Chromosomes Somatique de Neuf Enfants Mongolien, C.R. Acad. Sci., Paris, 248, 1721.

Money, J., Hampson, J. G., and Hampson, J. L. (1956): Sexual Incongruities and Psychopathology: the Evidence of Human Hermaphroditism, Bull. Fohns Hopk. Hosp., 98, 43.

Moore, K. L. and BArr, M. L. (I955): Smears from the Oral Mucosa in the Detection of Chromosomal Sex, Lancet, ii, 57.

, and Edwards, C. H. C. (1960): Medico-legal Aspects of Intersexuality: Criteria of Sex, Canad. med. Ass. F., 83, 709 .

Graham, M. L., and Barr, M. L. (1953): The Detection of Chromosomal Sex in Hermaphrodites from a Skin Biopsy, Surg. Gynec. Obst., 96, 641.

Muldal, S. and Ockey, C. H. (1960): The 'Double Male': A New Chromosome Constitution in Klinefelter's Syndrome, Lancet, ii, 492.

Nowell, P. C. and Hungerford, D. A. (1 960): Ætiology of Leukæmia, Lancet, i, i 13.

Patad, K., Smith, D. W., Therman, E., Inhorn, S. L., and Wagner, H. P. (I96o): Multiple Congenital Anomaly caused by an Extra Chromosome, Lancet, i, 790.

Plunkett, E. R. and BarR, M. L. (1956): Testicular Dysgenesis Affecting the Seminiferous Tubules, Principally with Chromatin-positive Nuclei, Lancet, ii, 853.

Polani, P. E., Briggs, J. H., Ford, C. E., Clarke, C. M., and Berg, J. M. (1960): A Mongol Girl with 46 Chromosomes, Lancet, i, $72 \mathrm{I}$.

Puck, T. T., Robinson, A., and TJıо, J. H. ( 1960): Familial Primary Amenorrhoea due to Testicular Feminization: A Human Gene affecting Sex Differentiation, Proc. Soc. exp. Biol. (N.Y.), ro3, 192.

RiIs, P. and Fuchs, F. (I 960): Ante-natal Determination of Fotal Sex in Prevention of Hereditary Diseases, Lancet, ii, 180 .

Tanner, J. M., Prader, A., Habich, H., and Ferguson-Smith, M. A. (1959): Genes on the Y Chromosome Influencing Rate of Maturation in Man, Skeletal Age Studies in Children with Klinefelter's (XXY) and Turner's (XO) Syndromes, Lancet, ii, $14 \mathrm{I}$.

'Turpin, R., Lejeune, J., Lafolrcade, J., and (jautier, M. (1959): Aberrations Chromosomique et Maladies Humaines, la Polydysspondylie a 45 Chromosomes, C.R. Acad. Sci., Paris, 248, 3636.

'T'Jio, J. H. and Levan, A. (I956): The Chromosome Number of Man, Hereditas (Lund), 46, I.

Wilkins, L. (1957) in The Diagnosis and 'Treatment of Endocrine Disorders in Childhood and Adolescence, p. 283. Oxford: Blackwell Scientific Publications.

-, Grumbach, M. M., and van Wyk, J. J. (1954): Chromosomal Sex in Ovarian Agenesis, f. clin. Endocr., 14, 1270.

Willis, R. A. (1958) in The Borderland of Embryology and Pathology, p. 44I. London: Butterworth. 